\title{
Striking a balance between community norms and human rights: The continuing struggle of the East African Court of Justice
}

\author{
Ally Possi* \\ Advocate of the High Court of Tanzania
}

\section{Summary}

The article exposes the difficult position in which the East African Court of Justice (EACJ) finds itself when faced with matters containing human rights allegations, which the Court is barred from deciding as such. The $E A C J$ is often called upon to draw a line between what might constitute a human rights case and a claim relating to an East African Community (EAC) norm which is not barred under article 27(2) of the East African Community Treaty. As the main judicial mechanism of the EAC, the EACJ is primarily mandated to interpret and apply EAC law, of which human rights form part. Despite the existing limitations, the EACI has clearly laid down its position that it cannot 'abdicate' exercising its interpretive mandate, even if a matter before it contains allegations of human rights violations. In doing so, the EACJ has indirectly protected human rights in the EAC through other forms of cause of actions, such as the rule of law and good governance. This contribution advances two key arguments: First, the EAC Treaty contains human rights norms that the EACI cannot escape from interpreting. Second, due to the continuing restrictions in adjudicating human rights, as well as the existing human rights norms in the EAC Treaty, the EACI is trapped in precarious attempts to balance the advancing of EAC norms, on the one hand, and adhering to the Treaty restrictions in adjudicating human rights, on the other.

Key words: East African Court of Justice; human rights; jurisdiction; subregional courts; African economic communities

LLB (Mzumbe), LLM (Cape Town), LLD (Pretoria); ally.possi@hotmail.com. This article is based on the author's LLD thesis prepared at the Centre for Human Rights, Faculty of Law, University of Pretoria. 


\section{Introduction}

Human rights form an important component in the contemporary agenda of international institutional law. The integration of human rights into various international organisations is one of the characteristics of a modern international community. This is evident in a number of international organisations that have made human rights one of their founding principles. Some organisations have gone even further by considering respect for human rights as one of the prerequisites for a state to be a party to such organisation. ${ }^{1}$ To ensure that member states and all other institutions in the international organisation adhere to treaty norms, a judicial organ is usually established. Over the last decade, in Africa, African regional economic communities have been at the forefront in realising human rights. These communities have established judicial organs which supervise their community activities. The role of African community courts in protecting human rights within their respective communities is widely acknowledged. $^{2}$

The East African Community (EAC), which was established in 1999, is made up of Burundi, Kenya, Rwanda, Tanzania and Uganda. The overarching goal of the EAC is to widen and deepen social, economic, political and cultural integration in order to improve the standard of life of the East African people. The EAC Treaty establishes the East African Court of Justice (EACJ), as the main judicial organ of the Community. The Court is primarily responsible for interpreting and applying EAC law. ${ }^{3}$ The Court is a creature of the express will of EAC member states as codified in the EAC Treaty. As such, the EAC] has the status of being an international court responsible for supervising EAC norms. ${ }^{4}$

1 See art 49 read with art 2 of the Treaty on the European Union; art 3(b) of the Treaty Establishing the EAC; art 3 of the Statute of the Council of Europe.

2 See LN Murungi \& I Gallinetti 'The role of sub-regional courts in the African human rights system' (2010) 7 SUR-International Journal on Human rights 119.

3 The EACJ is established under arts 9, 23(1) and 27(1) of the EAC Treaty. For an overview of the EACJ and its role in protecting human rights, see A Possi 'The East African Court of Justice: Towards effective protection of human rights in the East African Community' (2013) 17 Max Planck Yearbook of United Nations Law 173195; JE Ruhangisa 'The East African Court of Justice' in R Ajulu (ed) The making of a region: The reviving of the East African Community (2005) 95; TO Ojienda 'The East African Court of Justice in the re-established East African Community: Institutional structure and function in the integration process' (2005) 11 East African Journal of Peace and Human Rights 220-240, JE Ruhangisa 'The East African Court of Justice: Ten years of operations (achievements and challenges)' paper presentation during the sensitisation workshop on the role of the EAC) in the EAC integration, Kampala, 1-2 November 2011, http://www.eacj.org/docs/EACJ-Ten-Years-ofOperation.pdf (accessed 12 April 2014); SB Bossa 'A critique of the East African Court of Justice as a Human Rights Court' Conference paper on Human Rights Institutions in Eastern Africa, presented 26 October 2006, Arusha, Tanzania, http:/ /www.icj.org/IMG/_Speech_BOSSA_.pdf (accessed 12 March 2014).

$4 \quad$ Bossa (n 3 above) 9. 
As far as human rights jurisdiction is concerned, the EACJ does not have an explicit human rights mandate. Nonetheless, it may be claimed that through judicial activism, the Court has been playing an important role in protecting human rights within the Community. Article 27(2) of the EAC Treaty confers the power upon the Council of Ministers to adopt a protocol that would extend the current jurisdiction of the EACJ. The EACJ has laid down its position clearly that it cannot 'abdicate' exercising its interpretive mandate, even if a matter before it contains allegations of human rights. In doing so, the $E A C$ ) has been protecting human rights indirectly in the EAC through other forms of cause of actions, such as the rule of law and good governance.

Two key arguments are advanced in this contribution. First, the EAC Treaty contains human rights norms that the EAC] cannot escape from interpreting. Second, due to the continuing restrictions on adjudicating human rights, coupled with the human rights norms existing in the EAC Treaty, the EACJ is trapped between balancing advancing EAC norms, on the one hand, and adhering to the Treaty restrictions on adjudicating human rights, on the other. This undertaking has not been fulfilled adequately by the Court. This is due to the fact that there is a thin line between human rights and EAC norms, such as the rule of law, good governance and environmental issues that the Court has relied upon in deciding human rights-related cases so far.

The article has six sections. The first section is an introduction that outlines the scope of the article. Section two contains a general reflection on sub-regional courts in Africa and their role in realising human rights. This is important for a general understanding of the current involvement of these courts in realising human rights on the continent. Section three highlights the existing human regime in the EAC, arguing that the EAC Treaty has a human rights content that cannot be ignored by the EACJ. Section four deals with the role of the $E A C$ ) in the adjudication of human rights, while section five examines article 27(2) of the EAC Treaty, and provides some of the latest developments with regard to the protocol, aimed at extending and conferring upon the EACJ an explicit human rights mandate. Section six is a general conclusion.

\section{Rise of sub-regional courts and the realisation of human rights}

Considering the dynamics surrounding international law after World War II, it was not surprising that efforts to promote and protect human rights around the world were witnessed. Global and regional 
mechanisms for protecting human rights rose sharply. ${ }^{5}$ International courts and tribunals are among the most important means for the peaceful settlement of disputes. ${ }^{6}$ Through supranational organisations, states have established judicial organs with the primary task of adjudicating disputes and establishing the rule of law within their respective organisations. ${ }^{7}$ It is said that the existence of multiple international judicial bodies contributes to a degree of 'experimentation' and 'exploration' that might result in the advancement of the international legal order. ${ }^{8}$ With relevance to the emergence of sub-regional courts in Africa, on the one hand, the proliferation of international courts and tribunals in the region can be seen as a sign of a movement towards a rule of law based on a dispute settlement culture. On the other hand, the multiplication of international judicial bodies raises concerns when they arrive at 'divergent or even conflicting rulings', which has been the case on a number of occasions. ${ }^{9}$

It took a while for a regional court in Africa that would judiciously supervise the protection of human rights on the continent to be established. The African Court on Human and Peoples' Rights (African Court) was formed after the Organisation of African Unity (OAU) adopted the Protocol on the African Court in June 1998. The Protocol entered into force on 25 January $2004 .{ }^{10}$ As the main human rights court in Africa was struggling to establish its authority, sub-regional courts gradually started to be involved in protecting human rights by the middle of the 2000s. This started in the Economic Community of West African States (ECOWAS) in 2004, when Olajide Afolabi, a Nigerian businessman, brought a case against Nigeria for a violation of EAC law in the closing of Nigeria's border with Benin. During that time, the ECOWAS Treaty did not give individual access to the EACJ. As expected, the ECOWAS Court ruled that under the Court Protocol, only member states could institute cases.

The ruling triggered a lengthy discussion, spearheaded by the Court's judges, themselves, on the necessity of amending the Protocol to permit individuals to have standing before the Court. In 2005,

5 FO Vicuna 'Individuals and non-state entities before international courts and tribunals' (2001) 5 Max Planck Yearbook of United Nations Law 55.

6 RP Alford 'The proliferation of international courts and tribunals: International adjudication in ascendance' (2000) 94 American Society of International Law 165.

$7 \quad$ P Mahoney 'The international judiciary - Independence and accountability' (2008) 7 The Law and Practice of International Courts and Tribunals 315.

8 JL Charney 'The impact on the international legal system of the growth of international courts and tribunals' (1996) 31 NYU Journal on International Law and Politics 697700.

$9 \quad \mathrm{~N}$ Lavranos 'Regulating competing jurisdictions among international courts and tribunals' (2008) 68 Heidelberg Journal for International Law 576-577. For a general reflection on the conflicting jurisdiction and the proliferation of international courts and tribunals, see $Y$ Shany The competing jurisdictions of international courts and tribunals (International courts and tribunals series) (2003).

10 According to art 2 of the Protocol, the African Court complements the protective mandate of the African Commission. 
ECOWAS member states adopted a supplementary protocol that permitted individuals to bring disputes against member states. Beyond this monumental shift, the Council took the opportunity to review the jurisdiction of the Court to include human rights. Since clothing the ECOWAS Court with an explicit human rights mandate, the human rights jurisprudence of the ECOWAS Court has been a novelty on the continent. With such vigorous developments in ECOWAS at the time, other sub-regional courts, such the EACJ and the now moribund Southern African Development Community (SADC) Tribunal, tried to emulate what was a relatively immature success of the ECOWAS Court. Undoubtedly, the progress made by the ECOWAS Court, nevertheless, has had an influence on the current functioning of the EAC).

\section{Evidence of human rights in the EAC Treaty}

Human rights do not form part of the objectives of the EAC. They constitute governing principles to achieve the objectives of the Community. Article 6 of the EAC Treaty provides for fundamental principles which should be adhered to by member states, necessary for achieving the targeted EAC goals. When carrying out Community activities, member states are directed to adhere to good governance, including the principles of democracy, the rule of law, accountability, transparency, social justice, equal opportunities, gender equality, as well as the recognition, promotion and protection of human and peoples' rights in accordance with the provisions of the African Charter on Human and Peoples' Rights (African Charter). ${ }^{11}$ Article $7(2)$ of the EAC Treaty states that '[t]he [member states] undertake to abide by the principles of good governance, including adherence to the principles of democracy, the rule of law, social justice and the maintenance of universally accepted standards of human rights'. Apart from the founding principles of the EAC, there are other significant human rights-related features in the EAC Treaty. The recognition of and respect for human rights are among factors to be taken into account when considering a new member of the EAC. ${ }^{12}$ This reflects the commitment of EAC members to have a region that respects human rights.

The promotion of peace and security is one of the objectives of the EAC. ${ }^{13}$ By maintaining peace and security, a stable society is ensured and, therefore, a lack of peace and security automatically affects the realisation of human rights. ${ }^{14}$ The EAC member states agree on the importance of peace and security for social and economic

11 Art 6(d) EAC Treaty.

12 Art 5(3)(b) EAC Treaty.

13 Arts 5(1) \& 5(3)(f) EAC Treaty.

14 OC Ruppel 'Regional economic communities and human rights in East and Southern Africa' in JA Bösl \& j Diescho (eds) Human rights in Africa (2009) 304. 
development and the achievement of their objectives. ${ }^{15}$ Member states intend to strengthen co-operation to maintain regional peace and security. This will involve greater co-operation in cross-border conflicts, the establishment of regional disaster management mechanisms, and the establishment of common mechanisms for the management of refugees. ${ }^{16}$ When there is peace and security, there is an environment suited to investment and trade, which will even better suit the economic objectives of the EAC.

Gender equality is centre stage in East African integration. Gender equality is recognised as one of the fundamental principles of the EAC. ${ }^{17}$ Abiding by the principle of gender equality, member states have pledged to take into account the issue of gender balance when appointing staff members of the organs and institutions of the Community. ${ }^{18}$ Realising the role of women in social and economic development, member states, through appropriate and other legislative measures, are obliged to promote women's empowerment, to eradicate all legislation and customs which are discriminatory and to take all necessary measures that will eliminate prejudice against women. ${ }^{19}$

Furthermore, several measures have been taken in the EAC in order to comply with the provisions in the Treaty and to seek to improve the quality of life of women in the region. The final draft of the Community Framework on Gender and Community Development was adopted in 2006, seeking to cater for the rights of women in the region. In 2009, the East African Legislative Assembly (EALA) adopted a resolution encouraging member states to take 'urgent and concerted action to end violence against women'. ${ }^{20}$ Significantly, it called on member states to 'enhance the mainstreaming of gender and human rights into budgets' at the national level. ${ }^{21}$

AIDS being a pandemic, EAC member states have been called upon to take joint action in the prevention and control of HIV and AIDS, together with other communicable diseases. ${ }^{22}$ HIV and AIDS are given emphasis in the EAC due to their impact on human resources. They may spread rapidly due to the free movement of persons in the integration process.

15 Art 124(1) EAC Treaty.

16 Arts 124(3),(4) \&(5)] EAC Treaty.

17 Art 6(d) EAC Treaty.

18 Art 9(5) EAC Treaty.

19 Art 121 EAC Treaty.

20 ST Ebobrah 'Human rights development in African sub-regional economic communities during 2009' (2010) 10 African Human Rights Law Journal 236.

21 The EALA Resolution: Action to end violence against women in the EAC Region, http://www.eala.org/key-documents/doc_details/8-resolution-action-to-end-violen ce-against-women-in-the-eac-region-and-particularly-partner-states.html (accessed 12 January 2013).

22 Art 118 EAC Treaty. Ch 21 of the EAC Treaty has been dedicated to health, cultural and social activities in the region. 
Other human rights-related features of the EAC Treaty include the free movement of persons; the right to establishment and residence; labour services; ${ }^{23}$ agriculture and food security; ${ }^{24}$ and natural resources and environmental management. ${ }^{25}$ Member states are required to develop and adopt a common approach for improving the living standards of disadvantaged groups such as children, the elderly and persons with disabilities, through the rehabilitation and provision of, among others, foster homes, health care, education and training. ${ }^{26}$

Third generation rights, such as the right to a clean and healthy environment, are recognised within the EAC legal framework. A healthy environment is essential for human life. Sustainable environmental conditions promote the right to dignity and improve the health standards of people. In the EAC legal framework, EAC member states have adopted a Protocol on Environment and Natural Resources, providing closer co-operation in environmental and natural resource management. Member states are committed to observe the 'principle of the fundamental right of the people to live in a clean and healthy environment' ${ }^{27}$ The Protocol covers various aspects of the environment, such as water, wildlife, generic resources, climate change, energy and mining, biodiversity and forests. In Tanzania $v$ African Network for Animal Welfare, ${ }^{28}$ the appellant was aggrieved by the decision of the First Instance Division which ruled that it had jurisdiction to hear a case concerning allegations that the proposed super-highway project proposed by Tanzania would have an impact on the environment and climate of the Masai Maara National Park and the interests of the international community, through the designation by the United Nations Educational, Scientific and Cultural Organization (UNESCO) of the Serengeti National Park as a world heritage site. Ultimately, the Appellate Division held that the EAC) had jurisdiction to determine a case that involves environmental issues in exercising its duty of interpreting the EAC Treaty. ${ }^{29}$

It is debatable whether the principles provided in the EAC Treaty bind members. Article $38(1)(c)$ of the Statute of the International Court of Justice (ICJ) mandates the ICJ to use 'general principles of law recognised by civilised states' as a source of international law. ${ }^{30}$ In Kodi $v$ Council of the EU \& Another, ${ }^{31}$ the European Union (EU) Court

23 Ch 17 EAC Treaty.

Ch 18 EAC Treaty.

Ch 19 EAC Treaty.

Art 120(2) EAC Treaty.

Art 4(2)(a) Protocol on Environment and Natural Resources, 2005.

Appeal 3 of 2011, EAC Appellate Division.

Appeal (n 28 above), 14 of the judgment.

30 L Bartels 'Review of the role, responsibilities and terms of reference of the SADC Tribunal', World Trade Initiative Advisors (2011) 10

31 Kadi $v$ Council of the European Union and Commission of the European Communities, Case C-402/05 P, [2008] ECR I-6351. 
reaffirmed the importance of fundamental principles such as the rule of law, democracy and human rights that were common to member states for protecting legal order in the EU. In addition, in interpreting a treaty, the context of interpretation includes the Preamble, the main text and annexes to the treaty. ${ }^{32}$ It is on this basis that principles within the EAC Treaty are never read to have been intended to be merely inspirational; rather, they impose a legal obligation on member states and they are subject to interpretation by the EAC]. ${ }^{33}$

The ultimate goal of the EAC is to achieve a political federation. Whether such objective will be reached or not is another matter. However, in forming a political federation, the protection of human rights must be given prime consideration. Special attention to promoting and protecting human rights by the EAC organs and institutions is inevitable in order to deepen EAC integration. The EAC] needs to be given an expanded mandate to deal with human rights disputes. The lack of a human rights jurisdiction for the EAC) is an obstacle to realising the dream of having viable regional integration in East Africa. This argument is also supported by the EAC) when it stated: ${ }^{34}$

\begin{abstract}
National courts have the primary obligation to promote and protect human rights. But supposing human rights abuses are perpetrated on citizens and the state in question shows reluctance, unwillingness or inability to redress the abuse, wouldn't regional integration be threatened? We think it would. Wouldn't the wider interests of justice, therefore, demand that a window be created for aggrieved citizens in the Community [member state] concerned to access their own regional court ... for redress? We think they would.
\end{abstract}

On the face of it, as highlighted above, the EAC Treaty is enriched with provisions containing human rights norms. The existing human rights content in the EAC Treaty is the basis for the ever-increasing voice which advocates for the EACJ to be granted explicit human rights jurisdiction. It is also difficult to anticipate the EACJ not receiving any cases relating to a common market dispute, as an example, without touching on human rights. In such circumstances, the EACJ has to determine what constitutes a human rights case.

\title{
4 Human rights architecture of the EACJ
}

\subsection{Interpreting human rights norms in the EAC Treaty}

After showing that the EAC Treaty has a human rights content, I below reflect on the role of the EAC) in interpreting the EAC Treaty with respect to provisions with human rights elements.

32 Art 31(2) VCLT.

33 Plaxeda Rugumba $v$ Secretary-General of the EAC \& Attorney-General of Rwanda, Ref 8 of 2010, EACJ First Instance Division, para 37.

34 Sitenda Sebalu $v$ Secretary-General of the EAC \& Others, Ref 1 of 2010, EAC) First Instance Division 50. 
One of the intriguing challenges faced by international courts is treaty interpretation, the EAC) being no exception. ${ }^{35}$ The main purpose of treaty interpretation is to ascertain and give effect to the norms in the treaty. Articles 31 and 32 of the Vienna Convention on the Law of Treaties (VCLT) provide for the basic rules of treaty interpretation. The rules provided in the two articles are not 'an exclusive compilation of guidance on treaty interpretation', ${ }^{36}$ implying that there could be other factors relevant to interpreting a treaty. Article 31 of the VCLT provides that a treaty should be interpreted in good faith, taking into consideration the ordinary meaning to be given to the terms of the treaty in their context and in the light of its object and purpose. ${ }^{37}$

In interpreting a treaty, the scope of interpretation should include the main text along with the Preamble and annexures of the treaty. ${ }^{38}$ Interpretation rules require a treaty to be interpreted in good faith. ${ }^{39}$ This principle flows directly from the principle of pacta sunt servanda enshrined in article 26 of the Vienna Convention. Accordingly, under international law, there are three basic approaches to treaty interpretation. The first approach centres on the actual text of the treaty; the second looks at the intention of the parties to a treaty; and the third approach focuses on the object and purpose of the treaty. Reliance on the textual approach simply means a literal interpretation of the text in the treaty. With the second approach, on the object and purpose of a treaty, judges are likely to be called upon to define the object and purpose of the treaty. At this point, a judge-made law might be imminent. It goes without saying that any true interpretation of a treaty under international law must take cognisance of all the aspects of the agreement, 'from the words employed to the intention of the parties and the aim of the particular document ${ }^{40}$ Recourse may be had to supplementary means of interpretation. 41 As stated above, the insertion of human rights principles under the EAC Treaty was not meant to be a 'cosmetic' exercise. $^{42}$

When discharging its interpretative duties, the EAC) is duty bound to take into consideration the object and purpose of the EAC Treaty. On the one hand, because of the fact that the context of treaty interpretation includes the whole text of a treaty, together with the treaty's objectives and purposes, one can easily advance an argument that there is no reason for the EACJ to refrain from directly

35 See MN Shaw International law (2008) 932.

36 R Gardiner Treaty interpretation (2008) 36.

37 Art 31(1) VCLT.

38 Art 31(2) VCLT.

39 Art 31(1) Vienna Convention. See also A Aust Modern treaty law and practice (2004) 187.

40 Shaw (n 35 above) 933.

41 Art 32 Vienna Convention.

42 Ref 8 of 2010, EAC) First Instance Division, para 37. 
interpreting the human rights provisions in the EAC Treaty, even if there are limitations imposed under article 27(2) of the EAC Treaty. On the other hand, the EACJ will be presumed to be adjudicating human rights when its findings will be based on human rights, a mandate currently suspended by article $27(2)$ of the EAC Treaty. Under such premises, member states should confer on the EACJ an explicit human rights mandate as soon as possible. Potentially, the continuing presence of article 27(2) of the EAC Treaty might lead to a backlash between the EACJ and member states, as the Court can never escape touching on human rights when discharging its duties, because of the human rights content of the EAC Treaty.

EAC leaders are committed to fast-tracked regional integration in East Africa based on democratic values. Placing human rights in the EAC Treaty, as one of the governing principles of the Community, serves as a yardstick for monitoring the activities of EAC member states in their activities connected with EAC integration. Observance of human rights also provides the means of achieving the socioeconomic and political objectives of the EAC. Being the main judicial arm of the Community, the EACJ is properly positioned to supervise the fast-tracking of EAC integration by interpreting and applying EAC law in good faith and within the context of the EAC Treaty, as required by the VCLT. However, the EACJ cannot succeed in its mission of supervising EAC integration if an important aspect such as human rights is explicitly curtailed under the EAC Treaty.

\subsection{Judicial law making or purposive interpretation?}

The interpretive approach of the EAC) in matters that contain human rights claims may lead to the perception that the Court is trying to stretch EAC law in ways which EAC member states have not intended. With the present interpretive approach, indirectly, the EACJ is protecting human rights in the Community, which is an encouraging sign to litigants, but which may be a worrying trend to member states. This is evident due to the fact that, in all human rights-related cases, litigants have been asking the Court to interpret human rights violations in accordance with the African Charter, and member states have persistently disputed the Court's ability to entertain any human rights claim. One need not be reminded of how the EU Court judges transformed EU law. The EU Court was able to transform the Rome Treaty in to 'a de facto constitution' for the EU. ${ }^{43}$ This was possible due to the fact that the EU Court promoted EU objectives such as human rights, which were not extensively provided in the Treaty of Rome. A less bold bench could easily decline entertaining most of the cases that are admitted before the EACJ due to their human rights nature.

43 KJ Alter \& LR Helfer 'Nature or nurture? Judicial law making in the European Court of Justice and the Andean Tribunal of Justice' (2010) 64 International Organization 564. 
It could be argued that judicial creativity of the EACJ judges to protect human rights is in line with a literal interpretation of the EAC Treaty. Article 27(2) of the EAC Treaty mentions the human rights jurisdiction to be put on hold, but the same article is silent as regards democracy, good governance and the rule of law as well as all other provisions which have human rights elements, such as provisions relating to environmental issues. As such, the Court has been using the opportunity to freely interpret and find states to be in breach of the rule of law, democracy and good governance as provided for in the EAC Treaty. It is only the human rights jurisdiction of the EAC) that has always been questioned by respondents, but not the role of the Court to determine the liability of member states to preserve and protect the rule of law, democracy and good governance.

International judges, such as those of the EAC], are more likely to become expansionist law makers where they are supported by interlocutors and compliance constituencies, including government officials, advocacy networks, national judges and administrative agencies. ${ }^{44}$ Given the current trend of the EACJ's approach in cases with human rights elements, it could well be the foundation period for establishing an EAC constitutionalism, as was the case with the EU Court in the 1960s and 1970s. The EACJ judges have not crossed the boundaries of their interpretive mandate. With respect to human rights litigants, it is easy to commend the EAC)'s approach and classify it as judicial activism. As Alter and Helfer put it, '[i]nternational judicial decision making that clarifies ambiguities and fills gaps in treaties is an inherent part of judging'. ${ }^{45}$ Therefore, with respect to human rights principles provided in the EAC Treaty and the limitations imposed under article 27(2), EACJ judges have attempted to cover the ambiguity concerning their human rights mandate. EACJ judges, as any other international court judge, are supposed to 'clarify the meaning of ambiguous international rules and apply them to unforeseen contexts'. ${ }^{46}$

Because of the fact that the EACJ has developed its own human rights profile through judicial activism, the question might be whether such a strategy is best suited only for a transitional period or for a more permanent approach to human rights; and whether it can navigate the existing obstacles imposed under article 27(2) of the EAC Treaty. Before engaging in the issue at hand, a few points should be made. The involvement of civil society, legal practitioners and political actors has to some extent turned the EACJ into a forum for power struggles and the 'vindication of rights claims'. ${ }^{47}$ The EAC)'s

44 Alter \& Helfer ( 433 above) 563.

45 Alter \& Helfer 586.

46 LR Helfer \& KJ Alter 'Legitimacy and lawmaking: A tale of three international courts' (2013) 14 Theoretical Inquiries in Law 481.

47 J Gathii 'Mission creep or a search for relevance: The East African Court of Justice's human rights strategy' (2013) 24 Duke Journal of Comparative and International Law 231249. 
involvement in human rights is not an exception. It is part of a growing trend towards a rights-based approach adopted by most supranational organisations. ${ }^{48}$ East African integration is not solely established for economic integration. ${ }^{49}$ EAC member states strive to ${ }^{50}$

develop policies and programmes aimed at widening and deepening cooperation among the [member states] in political, economic, social and cultural fields, research and technology, defence, security and legal and judicial affairs, for their mutual benefit.

Indeed, the EAC) is not a human rights court. It is a community court entrusted with the role of interpreting and applying the EAC Treaty. Whether the EAC) is to deal with trade or human rights or to be an appellate court in the region is at the discretion of member states. Despite the existing limitations to adjudicate human rights disputes, it is undeniable that the EACJ has adopted some kind of judicial activism when adjudicating cases with human rights allegations. In such circumstances, it is likely to provoke controversy among member states. It can also be propounded that the continuing politicisation of the EACJ's human rights jurisdiction may have been caused by the Court's activism. As a matter of fact, judicial activism can easily lead to unwanted results, particularly when a court is called upon to make judgments in sensitive areas where it lacks jurisdiction, when presiding judges are not conversant with the matter in question and, with the case of supranational courts, judicial activism may lead to a negative response from member states because they are displeased with the kind of judicial behaviour adopted by the judiciary. ${ }^{51}$ While the EACJ's bravery in adjudicating cases with human rights allegations is commendable, one should also be skeptical about the Court's direct involvement in human rights. Because of the fact that EAC member states are parties to the African Court, direct involvement of the EAC] in human rights might result in conflicting jurisdiction, consequently yielding forum shopping and jurisprudential concerns.

The EACJ's present technique of invoking the rule of law as the basis for adjudicating cases with human rights allegations is the right path for the Court to take. However, the approach is not sustainable if the Court is to effectively protect human rights in the region. It is submitted that the current judicial activism adopted by the EACJ in human rights-related cases is only suitable for the current situation. It is hoped that the EACJ's adoption of a rights-based approach is a stepping stone towards having an explicit human rights mandate in

48 As above.

49 See art 5 of the EAC Treaty.

50 Art 5(1) EAC Treaty.

51 For a general reflection of judicial activism of international judiciaries, see E McWhinney 'The International Court of Justice and international law making: The judicial activism/self-restraint antinomy' (2006) 5 Chinese Journal of International Law 3; P Kooijmans 'The ICJ in the 21st century: Judicial restraint, judicial activism, or proactive judicial policy' (2007) 56 International and Comparative Law Quarterly 741. 
the near future. It would be an enormous leap for the EACJ to interpret human rights norms beyond its current stance. In the event that the EACJ attempts to adjudicate human rights disputes beyond its present approach, there would be a risk of inviting a political response from member states. One would easily conclude that the EACJ's current approach in human rights-related cases is a cautious but progressive judicial law-making strategy.

\subsection{Landmark cases on human rights}

The first case relating to human rights to be determined by the EACJ was Katabazi \& Others v Uganda. ${ }^{52}$ The matter involved 14 applicants who were arrested and charged with treason in 2005. On 16 November 2006, the High Court of Uganda was in the process of granting bail to the 14 suspects. During the process, the Ugandan security officials interfered with the preparation of bail documents and re-arrested the suspects, who were later charged in a military court with terrorism and the unlawful possession of firearms. The Ugandan Law Society successfully challenged before the Constitutional Court of Uganda the constitutionality of the conduct by the Ugandan security officials for their interference with the lawful court process. ${ }^{53}$ Despite the ruling by the Constitutional Court of Uganda that the applicants should be released, this was not done. This caused the applicants to seek legal relief before the EACJ. The applicants averred that the interference with the lawful court process by Ugandan security officials and the failure by the Ugandan government to comply with the decision of the Constitutional Court of Uganda was contrary to articles $6,7(2)$ and $8(1)$ (c) of the EAC Treaty.

One of the key issues before the Court was whether the EAC] had jurisdiction to adjudicate a human rights-related issue. Both the Secretary-General and the Attorney-General of Uganda opposed the jurisdiction of the EACJ to deal with human rights matters, lamenting the fact that such jurisdiction awaits the adoption of a protocol that would extend the Court's mandate, as provided for in article 27(20) of the EAC Treaty. The EACJ was of the view that it may not determine matters concerning the violation of human rights per se; as it is clear that jurisdiction with respect to human rights requires a determination of the Council and a conclusion of a protocol to that effect. ${ }^{54}$ The EAC) extensively assessed the objectives ${ }^{55}$ and principles of the EAC. The $E A C$ J was conscious of recognising a number of objectives of the

52 Katabazi \& Others $v$ Attorney-General of Uganda Ref 1 of 2007.

53 Uganda Law Society v Attorney-General of Uganda Constitution Petition 18 of 2005. The applicant applied for orders and relief as provided for in arts 50(1) and (2) and 137(3) of the Constitution of Uganda.

54 Katabazi case (n 52 above) para 34.

55 There are views that the objectives clauses within a treaty do not create independent or substantive grounds for granting relief. See JT Gathii 'The underappreciated jurisprudence of Africa's regional trade judiciaries' (2010) 12 Oregon Review of International Law 262. 
EAC, particularly the intention of EAC member states to harmonise programmes and policies in different fields, including legal and judicial matters. ${ }^{56}$ After considering the objectives and founding principles provided in the EAC Treaty, the Court stated: ${ }^{57}$

While the Court will not assume jurisdiction to adjudicate on human rights disputes, it will not abdicate from exercising its jurisdiction of interpretation under article $27(1)$ merely because the [r]eference includes an allegation of human rights violation.

After holding that it has jurisdiction as provided for in article 27 of the EAC Treaty, the EACJ pondered the principle of the rule of law in assessing whether the conduct of the Ugandan security officials was in breach of the EAC Treaty. The principle of the rule of law is not limited in article 27(2) of the EAC Treaty. Therefore, the finding of the case was relying on a breach of the rule of law and not human rights.

The position in the Katabazi case is emphasised by the EAC) in a number of subsequent cases. It is the position of the Court that it will interpret any allegation before it, regardless of such allegation containing a human rights claim. In Samuel Mohochi $v$ AttorneyGeneral of Uganda, ${ }^{58}$ the First Instance Division stated that the envisaged extension stipulated in article 27(2) of the EAC Treaty in no way intends to limit the Court from interpreting and applying any provision of the EAC Treaty, including all provisions making reference to human rights. ${ }^{59}$

After the Katabazi case, more cases touching on human rights violations started to come before the EAC). When the two-tier court structure became operational in the first few cases that had human rights allegations in the two divisions, the difference in terms of their approach in interpreting the EAC Treaty was evident. In Independent Medical Legal Unit $v$ Attorney-General of Kenya, ${ }^{60}$ the First Instance Division directly exercised its interpretive jurisdiction of the EAC Treaty, without linking the alleged cause of action to the rule of law. In that case, the applicant alleged that the failure by the Kenyan government to prevent, investigate and apprehend the perpetrators of the post-2007 election violence in the Mt Elgon District, causing the death, torture and inhuman and degrading treatment of over 3000 civilians, was a breach of the established EAC principles as provided for in articles $6(\mathrm{~d})$ and $7(2)$ of the EAC Treaty. Apart from acknowledging that it had jurisdiction to interpret provisions with reference to human rights, the First Instance Division went further and held that the omission by the Kenyan government contravened not

56 See art 5(1) of the EAC treaty.

57 Katabazi case (n 52 above) para 39.

58 Samuel Mohochi v Attorney-General of Uganda Ref 1 of 2011, EAC) First Instance Division.

59 Mohochi case (n 58 above) para 26.

60 Independent Medical Legal Unit v Attorney-General of Kenya Ref 3 of 2010, EAC) First Instance Division. 
only the principles provided for in the EAC Treaty, but also the Constitution of Kenya and a number of international human rights instruments, such as the Universal Declaration of Human Rights (Universal Declaration). ${ }^{61}$

In the Plaxeda Rugumba case, ${ }^{62}$ the applicant alleged that the act of the government of Rwanda of arresting and detaining Seveline Rugigana Ngabo, who was a lieutenant-colonel in the Rwanda Patriotic Front (RPF), was contrary to articles 6(d) and 7(2) of the EAC Treaty. The Court held that it would be a dereliction of the Court's oath of office to desist from exercising its jurisdiction to interpret the EAC Treaty, even when the reference before it relied on articles $6(d)$ and $7(2)$ of the EAC Treaty. The Court stressed its mandate to interpret the EAC Treaty by stating as follows: ${ }^{63}$

$[T]$ here is no doubt that the use of the words '[o]ther original, [a]ppellate, [h] uman [r]ights and [o]ther [j]urisdiction ...' is merely in addition to, and not in derogation to, existing jurisdiction to interpret matters set out in [a]rticles 6(d) and 7(2). That would necessarily include determining whether any [p]artner [s]tate has 'promoted' and 'protected' human and peoples' rights in accordance with the provisions of the African Charter on Human and Peoples' Rights and the [a]pplicant is quite within the treaty in seeking such interpretation and the Court quite within its initial [j] urisdiction in doing so and it will not be shy in embracing that initial [j]urisdiction.

The First Instance Division took a more progressive approach than the Appellate Division in interpreting the EAC Treaty. Contrary to the Appellate Division, the First Instance Division was not hesitant to base its findings on direct human rights values contained in the EAC Treaty. It did not rely on other forms of cause of action which are not restricted under article 27(2) of the EAC Treaty. By using the phrase 'in addition to, and not in derogation to', the First Instance Division considered the protocol that would extend the jurisdiction of the EAC] to deal with human rights cases to be an addition to the current interpretive jurisdiction. In other words, the Court, as it had decided in that case, was of the view that the current jurisdiction that it possessed empowered it to interpret, analyse and reach its findings based on human rights norms provided for in the EAC Treaty and other human rights instruments, without finding a link to the rule of law.

The decision of the First Instance Division in the Rugumba case sheds some light on the ambiguity on the interpretive mandate of the $E A C$ J. It might be straightforward for one to conclude that, as long as the Court is empowered to interpret the EAC Treaty, taking into consideration the Treaty principles and objectives, there is no reason for the EACJ to refrain from its current mandate of interpreting directly all the EAC Treaty provisions and to make findings based on human

61 Ref 3 of 20104.

62 n 33 above.

63 Plaxeda Rugumba case (n 33 above) para 23. 
rights values even without using other forms of cause of action as a path to adjudicate human rights-related cases. From the experience of the SADC Tribunal, it is clear that a mere reference to human rights in a constitutive instrument of an international court is sufficient for such courts to directly interpret human rights provisions in the treaties and to make findings in relation to human rights violations. ${ }^{64}$ However, the situations in the SADC Tribunal and the EACJ must be made clear. The SADC Tribunal did not contain any provision close to article 27(2) of the EAC Treaty. On the contrary, the Tribunal had a mandate to develop its own jurisprudence when exercising its interpretive mandate. ${ }^{65}$

The interpretive approach adopted by the First Instance Division in both the Rugumba and Independent Medical Legal Unit cases is not in line with that of the Appellate Division in cases that relate to human rights. The Appellate Division has always been clear in its approach when interpreting cases that have human rights claims. It uses other forms of causes of action, such as the rule of law, as an escape route to interpret the EAC Treaty, based on human rights values as provided for in the Treaty. It should be pointed out that the judgments of the First Instance Division in Rugumba and Independent Medical Legal Unit were delivered after the amendment of the EAC Treaty that established a two-tier court structure. The case of Katabazi was used as a precedent by the First Instance Division in the two cases. These two cases had taken a greater judicial activist approach than in the Katabazi case, simply by directly exercising its interpretation jurisdiction of human rights provisions without linking human rights with a violation of the rule of law. The two cases also made reference to other human rights instruments not mentioned in the EAC Treaty, such as the Universal Declaration. ${ }^{66}$

The Appellate Division has made it clear that for the EACJ's jurisdiction to be triggered in references which relate to human rights, a cause of action has to be instituted distinct and separate from human rights. This requirement was not clearly articulated in the Katabazi case. In the Independent Medical Legal Unit case, ${ }^{67}$ the Appellate Division was of the view that the First Instance Division ought to have delved into the cause of action that is distinct from human rights violations, thus, acquire the basis for its jurisdiction, ${ }^{68}$ a position that was later reaffirmed by the Appellate Division in the Rugumba case.

Further, in cases concerning EAC Common Market or Customs Union integration activities, it is highly unlikely the EACJ will not be

$64 \mathrm{~L}$ Bartels Review of the role, responsibilities and terms of reference of the SADC Tribunal (2011) 10.

65 Art 21(b) of the defunct SADC Tribunal Protocol.

66 See J Crawford Brownlie's principles of public international law (2012) 634.

67 Appeal 1 of 2011, EACJ Appellate Division.

68 Appeal 1 (n 67 above) 10-11. 
called upon to interpret human rights provisions. In what is already seen as the court's human rights mission, it will continue interpreting the EAC Treaty 'in its own way as it is used to without any fear or favour'. ${ }^{69}$

In Samuel Mohochi v Attorney-General of Uganda, ${ }^{70}$ the applicant arrived at Entebbe International Airport on 13 April 2011 and was denied entry into Uganda without being given a reason. He was then restrained, confined and detained in the offices of the Uganda Immigration Department at the airport from 09:00 to 15:00, when he boarded a flight back to Kenya. The respondents argued that the applicant was a prohibited immigrant in Uganda. Due to the nature of the case, the EACJ found itself analysing issues concerning free movement and discrimination, which are human rights-related aspects.

During the trial, the Attorney-General defended the actions of its state officials by submitting that Uganda was an independent state and not subject to the EAC. ${ }^{71}$ This submission by the AttorneyGeneral might be a reflection of a lack of awareness of the legal regime of the EAC upon member states, or a continuation of the attitude of member states who are reluctant to surrender some of their sovereignty to the EAC. As in the case of all EAC member states, Uganda gave the EAC Treaty the force of law in its territory. ${ }^{72}$

The main issue of contention was whether Uganda is entitled to deny an EAC citizen entry into its territory, given the provisions of sections 52 and 66(4) of Uganda's Citizenship and Immigration Control Act, and articles 104 and 7 of the EAC Treaty and Common Market Protocol respectively. Article 104 of the EAC Treaty and article 7 of the Protocol guarantee the free movement of persons, labour, services, and the right of establishment and residence in the Community. The Court found that the actions of Ugandan immigration officials were in violation of the freedom of movement of the applicant, which constituted part of the foundational principles of the Common Market and a violation of article 104 of the Treaty. ${ }^{73}$

Most of the cases that the EACJ receive are related to human rights. The EACJ has already developed a strong reputation in the region as a forum where democracy, the rule of law and human rights have the potential of being protected. Due to the limitations imposed under article 27(2) of the EAC Treaty, the prospects of the EACJ being a human rights protector are stalled. The above cases reveal that the $E A C J$ relies heavily on other causes of action, such as the rule of law,

69 A response from the Principal Judge of the EACJ, Jean Bosco Butasi, in an interview held on 4 December 2013.

70 Ref 1 of 2011, EACJ First Instance Division.

71 Mohochi case (n 58 above) para 45.

$72 \mathrm{Sec} 3(1)$ of the East African Community Act, 2002 of Uganda provides that '[the treaty as set out in the Schedule to this Act shall have force of law in Uganda'.

73 Mohochi case (n 58 above) para 112. 
democracy and good governance which have not been circumscribed under article $27(2)$ of the EAC Treaty.

The question could be whether rule of law issues are not human rights issues. The response to this question is debatable, but what is certain is that the EAC) will always find itself receiving matters which are of a human rights nature. Litigants, as has always been the case, will attempt to pass their human rights agenda before the EACJ by using the Court's approach, that is, by relying on other causes of action, such as the rule of law. In the process, there is a likelihood that the EACJ might be stringent or might change its current approach on cases that touch on human rights.

\section{Towards an explicit human rights mandate?}

\subsection{The tyranny of article $27(2)$}

Regardless of the existence of human rights provisions in the EAC Treaty, member states have impeded the EAC)'s effectiveness in protecting human rights by inserting article $27(2)$ into the EAC Treaty. Article $27(2)$ is often invoked by respondents before the EAC], particularly on matters which have human rights allegations. The provision is simply used as a protective shield by member states to escape any liability from the breach of an EAC obligation. States tend to question the competence of the Court to determine what they have termed to be human rights claims. In such circumstances, the $E A C$ J is mostly found wanting. On the one hand, the Court seems to be sceptical of the repercussions if it is to base its findings on human rights values. The EACJ is obviously cautious of any backlash if it is to interpret human rights norms in the EAC Treaty in a more progressive manner. On the other hand, the Court does not want to lose its legitimacy with litigants by being seen to abdicate its interpretive duties. To balance the two scenarios, the EACJ carefully interprets the EAC Treaty when dealing with cases with human rights allegations, so as not to exercise its jurisdiction beyond the established boundaries. It is because of this that it can be said that article 27(2) of the EAC Treaty brings confusion to both the EACJ and its litigants regarding the Court's mandate on human rights provisions under the EAC Treaty. This has been evident in the persistent filing of cases containing human rights allegations before the Court and the continuing denial of the Court's powers to entertain such matters. Litigants still believe that the EACJ is in a position to give a human rights finding. Respondents invoke article 27(2) of the EAC Treaty whenever faced with human rights allegations before the EACJ. With the continuing delays and lack of political commitment to adopt a protocol that would give the EACJ an explicit human rights mandate, article 27(2) will continue to raise alarm over the ability of the EACJ to interpret EAC Treaty provisions which make reference to human rights. In such circumstances, the EAC) is currently ineffective, as it is placed in a vulnerable position to the extent of interpreting the EAC 
Treaty cautiously. With respect to human rights, the Court will continue to be restricted in making findings based on human rights.

\subsection{Protocol to extend the jurisdiction of the EACJ to include human rights}

Article 27 of the EAC Treaty needs to be amended or a new protocol has to be adopted for the EACJ to have an explicit human rights mandate. In the spirit of fast-tracking the EAC integration, the EAC Secretariat identified an urgent need to adopt a protocol that would extend the jurisdiction of the EACJ in order to effectively supervise the activities of the Community. ${ }^{74}$ The Council approved that decision on 9 April 2005, leading to the preparation of a Zero Draft Protocol by the Secretariat for the extension of the jurisdiction of the EACJ. The expansion of the EACJ's jurisdiction is an ongoing battle by civil society and all stake holders in the region. The business community and law societies of East Africa once called for the Court to have trade, human rights and appellate jurisdiction. The then President of the East African Magistrates and Judges Association once stated: ${ }^{75}$

The formation of the East African Court of Appeal is a necessary and overdue step. We need a court of the highest resort in East Africa whose decisions bind all our national courts. The world trend now is to use international norms and standards to interpret national laws ... Further delay in establishing the East African Court of Appeal will just leave us behind while other regions forge ahead.

After a series of meetings, the Sectoral Council's meeting held in January 2009 had a number of recommendations. First, the extended jurisdiction of the EAC should not include an appellate jurisdiction as this will be contrary to the constitutional provisions of the Court's hierarchy of member states. Second, the Court should not have human rights jurisdiction as the member states are already parties to the African Court. Third, the Secretariat 'should take into account the original jurisdiction vested in the national courts in commercial matters in order not to overwhelm [the EACI] with litigation' ${ }^{76}$ In another meeting held in February 2009, the Sectoral Council directed member states, when discussing the Zero Draft Protocol, to consider, among other things, a recommendation that, pending the attainment of a political federation, the application and interpretation of universal human rights jurisdiction should be left to the national courts and should be determined at national level. ${ }^{77}$ On 30 November 2013, the EAC Summit approved the recommendation of the Council to extend the jurisdiction of the EACJ to cover trade and investment disputes as

74 Revised background paper on the 13th meeting of the Sectoral Council in legal and judicial affairs, 12-16 March 2012, Arusha, Tanzania, 4.

75 The President of the East African Magistrates and Judges Association during the association's Annual General Meeting held in Dar es Salaam in January 2004, quoted by Ruhangisa (n 2 above).

76 Revised background paper (n 74 above) 6.

77 Revised background paper 4-5. 
well as matters associated with the EAC Monitory Union. ${ }^{78}$ In respect of human rights and matters concerning crimes against humanity, the Summit directed the Council of Ministers to work with the African Union. This decision of the Summit is a turn of events, considering the fact that since 2012 it was calling upon the Council to expatiate the process of granting the EACJ jurisdiction on matters connected to crimes against humanity. On 26 April 2012, the East African Legislative Assembly adopted a Resolution requesting the EAC Council of Ministers to request the transfer of Kenyan cases currently before the International Criminal Court to the EAC). ${ }^{79}$ On 28 April 2012, the Summit endorsed the EALA Resolution and instructed the EAC Council of Ministers to examine the possibility and expedite the extension of the EACJ's jurisdiction to cover international crimes. ${ }^{80}$ The current draft Protocol does not confer on the Court human rights or appellate jurisdiction. Instead, the Protocol intends to extend the Court's jurisdiction to deal with commercially-related matters. ${ }^{81}$

\subsection{Efforts to speed up the process}

The lack of political will to adopt a protocol which is to bestow the EACJ with an explicit human rights mandate prevents the majority of victims to access the EACJ. In Sitenda Sebalu $v$ Secretary-General of the $E A C \&$ Others, ${ }^{82}$ the applicant, after having exhausted the local courts, sought to appeal to the EAC], only to discover that the EACJ was not an appellate court. Following this, the applicant, displeased with the reluctance shown by EAC member states, specifically Uganda, to adopt the protocol conferring on the EACJ appellate and human rights jurisdiction, sought the Court's declaration that the undue delay in adopting the protocol was against the principle of good governance, observance of the rule of law and democracy as provided in the EAC Treaty. While upholding the prayers sought by the applicant, the EAC) further stressed that regional integration would be in danger when member states are unwilling or reluctant and lack the ability to protect human rights at the national level and at the same time denying their citizens access to the EACJ for such redress. ${ }^{83}$ The views expressed by the EACJ emphasises that the Court, itself, feels it has a strong role to play in protecting human rights in the region. This is evident when the Court stated that the delay to extend the jurisdiction of the EACJ contravenes the principles of good governance as stipulated in article 6 of the Treaty.

78 Communique of the 15th ordinary summit of the EAC Heads of State, para 15.

79 See the EACJ Resolution 'Seeking to try Kenya 2007 general elections aftermath accused persons at EAC], not ICC' http://www.eala.org/component/docman/ cat_view/45-key-documents/46-resolutions. html (accessed 23 February 2014).

80 See the Communique of the EAC Summit, 28 April 2012.

81 Part E of EACJ Revised Protocol to operationalise the extended jurisdiction of the EACJ.

82 Sitenda Sebalu (n 34 above).

83 Ref 1 of 2010, EACJ First Instance Division 40. 
Being dissatisfied with the progress of expanding the jurisdiction of the EACJ, Sebalu approached the EACJ for a second time. He questioned its compliance with the EACJ's earlier decision which was in his favour. ${ }^{84}$ This came after the Council of Ministers/Sectoral Committee on Legal and Judicial Affairs, through its meetings held on 2-3 November 2011 and 12-14 March 2012, had revised the Zero Draft Protocol and precluded the appellate and human rights jurisdiction of the EACJ as initially envisaged. Consequently, Sebalu referred the matter to the EACJ with two major claims. First, the applicant was of the view that the failure by the Council of Ministers to implement the decision of the Court, Reference I of 2010, which ordered the expeditious adoption of a protocol for expanding the jurisdiction of the EACJ, amounted to contempt of court. Second, $\mathrm{Mr}$ Sebalu contested that the act of precluding human rights in the present Draft Protocol that had earlier been adopted from the Zero Draft Protocol which had human rights and appellate jurisdiction for the $E A C]$, was an infringement of the fundamental principles provided for in the EAC Treaty.

When determining the matter, the EACJ was not hesitant to hold that the failure by the Council of Ministers/Sectoral Committee on Legal and Judicial Affairs to implement the judgment of the Court in Reference 1 of 2010 contravened article 38(3) of the EAC Treaty and amounted to contempt of court. 85 On whether the act of changing the Draft Protocol was an infringement of Community principles, the EAC) was of the view that the Protocol was still being revised and, therefore, it could not fault the Council at that stage. ${ }^{86}$ Member states are required to take all necessary measures to implement the judgments of the EAC) without any foreseeable delays. 87 This is to ensure that the judgments of the EACJ are not delivered in vain. It was stated in the second Sebalu case that the Attorney-General of Uganda had attempted to appeal against the decision on Reference I of 2010. The fact that there is not an order of stay of execution from the Court on the Sebalu decision in Reference 1 of 2010, the judgment in that reference of the Court remains to be valid and has to be complied with, and failure amounts to contempt of court.

In spite of existing pressure from many quarters of stakeholders calling for the EACJ to be granted a human rights mandate, EAC leaders remain reluctant to do so. As events are unfolding, it seems that the EACJ will not be granted an explicit human rights mandate in the near future. There is also an indication that EAC political leaders have realised the complications with regard to criminal jurisdiction of the EACJ. Nevertheless, human rights remain a key element in the current East African integration process.

84 Sitenda Sebalu $v$ Secretary-General of the EAC \& Others, Ref 8 of 2012, EAC) First Instance Division.

85 Ref 8 of 2012, EACJ First Instance Division, para 49.

86 n 85 above, paras 67-68.

87 Art 38(3) EAC Treaty. 


\section{Conclusion}

The article has shown that article 27(2) of the EAC Treaty has so far placed the EACJ in a precarious position. While the Court is firm in safeguarding EAC norms, article 27(2) circumscribes the EACJ from effectively protecting human rights in the Community. When exercising its mandate in matters that touch on human rights, the $E A C$ ) is often found wanting. Thus, the Court is placed in a position to choose what constitutes a human rights violation. At present, the Court has failed clearly to draw the line to distinguish between the two. As it stands, the EACJ's jurisprudence attempts to strike a balance between human rights limitations and Community norms enshrined in the EAC Treaty. On a few occasions, the EACJ First Instance Division has tried to practise judicial activism by interpreting the EAC Treaty in conjunction with various international human rights instruments. This was overruled by the Appellate Division. It is concluded that the EACJ's current approach when dealing with human rights-related cases shows encouraging signs to litigants, that it has the potential to protect human rights in the region, a trend that should not be discouraged. 